\title{
A NEW FORMULATION OF CINNAMON OIL AND CHITOSAN DEPOLYMERIZED AGAINST OPPORTUNISTIC MICROORGANISMS DURING WOUND HEALING
}

\author{
MARÍA LUISA DEL PRADO-AUDELO ${ }^{1,2}$, ADRIANA ESTELA HERNÁNDEZ-TENORIO ${ }^{1}$, \\ MAYKEL GONZÁLEZ-TORRES ${ }^{3}$, JONATHAN J. MAGAÑA ${ }^{4}$, ROBERTO SÁNCHEZ-

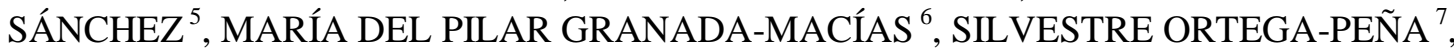 \\ HERNÁN CORTES ${ }^{4}$, GERARDO LEYVA-GÓMEZ ${ }^{1 *}$
}

\author{
${ }^{1}$ Department of Pharmacy, Faculty of Chemistry, National Autonomous University of Mexico, Ciudad Universitaria, Circuito \\ Exterior S/N, Del. Coyoacán, Mexico City, Mexico \\ ${ }^{2}$ Graduate Laboratory in Pharmaceutical Technology, FES-Cuautitlán, National Autonomous University of Mexico, \\ Cuautitlán Izcalli, Mexico \\ ${ }^{3}$ CONACyT-Biotechnology Laboratory, National Institute of Rehabilitation Luis Guillermo Ibarra Ibarra, Mexico City, Mexico \\ ${ }^{4}$ Genomic Medicine Laboratory, Department of Genetics, National Center for Research and Attention to Burns (CENIAQ), \\ National Institute of Rehabilitation-Luis Guillermo Ibarra Ibarra (INR-LGII), Mexico City, Mexico \\ ${ }^{5}$ Tissue Engineering Unit Cell Therapy and Regenerative Medicine, National Institute of Rehabilitation Luis Guillermo \\ Ibarra Ibarra (INR-LGII), Mexico City, Mexico \\ ${ }^{6}$ Department of Biology, Faculty of Chemistry, National Autonomous University of Mexico, Ciudad Universitaria, Circuito \\ Exterior S/N, Del. Coyoacán, Mexico City, Mexico \\ ${ }^{7}$ Laboratory of Infectology, National Institute of Rehabilitation Luis Guillermo Ibarra Ibarra, Mexico City, Mexico
}

*corresponding author: gerardoleyva@hotmail.com

Manuscript received: September 2020

\begin{abstract}
Infectious processes may delay wound healing. In this regard, there are diverse treatments available to prevent infections and promote wound healing. However, many of these present drawbacks, such as bacterial resistance, decrease their efficacy. In this respect, chitosan, a natural polymer with antibacterial and antifungal properties, may be useful in the process of skin repair. In this work, a cinnamon oil-based formulation with chitosan modified by gamma irradiation was developed. Moreover, disodium EDTA was added to create a combined antimicrobial effect against infections. The novel formulation showed percentages of inhibition of $43.64 \%$ for E. coli, $42.86 \%$ for P. aeruginosa, $80.27 \%$ for C. albicans, and $42.31 \%$ for $S$. aureus, as well as antibiofilm activity against $P$. aeruginosa. Our results suggest that the obtained formulation could be a new alternative treatment for chronic wounds.
\end{abstract}

\section{Rezumat}

Procesele infecțioase pot întârzia vindecarea rănilor. În acest sens, există diferite tratamente disponibile pentru prevenirea infecțiilor și vindecarea rănilor, dar rezistența bacteriană încă rămâne o problemă. În acest sens, chitosanul, un polimer natural cu proprietăți antibacteriene și antifungice, poate fi util în procesul de reparare a pielii. În această lucrare a fost elaborată o formulare pe bază de ulei de scorțișoară cu chitosan modificat prin iradiere gamma. Mai mult decât atât, EDTA disodic a fost adăugat pentru a crea un efect antimicrobian combinat împotriva infecțiilor. Noua formulare a înregistrat procente de inhibiție de $43,64 \%$ pentru $E$. coli, $42,86 \%$ pentru $P$. aeruginosa, 80,27\% pentru $C$. albicans şi $42,31 \%$ pentru $S$. aureus, precum şi activitate antibiofilm împotriva $P$. aeruginosa. Rezultatele obținute sugerează că formularea ar putea fi un nou tratament alternativ pentru plăgile cronice.

Keywords: cinnamon oil, chitosan, gamma radiation, infections

\section{Introduction}

A wound is defined as a disruption to normal anatomical structure and function [28]. According to the U.S. National Institute of Health, $80 \%$ of human infections involve mechanisms of antibacterial resistance, which delay wound healing [6]. These mechanisms are mediated by bacterial biofilms; in these systems, microbial colonies are immobilized within a matrix composed of polysaccharides, proteins, nucleic acids, and lipid molecules, conferring them tolerance to antibiotics and immunological protection [30]. In recent years, interest in essential oils as treatments against biofilm formation has increased due to its potential to decrease antimicrobial resistance [13]. In this regard, Cinnamon essential oil (CO) is an important candidate being composed mainly of transcinnamaldehyde, o-methoxy-cinnamaldehyde, cinnamyl aldehyde, benzaldehyde, phenyl ethanol, borneol, 
FARMACIA, 2021, Vol. 69, 3

eugenol, coumarin, and cinnamic acid [29]. CO has demonstrated activity against biofilm cultures of Streptococcus mutans and Lactobacillus plantarum [23]; the effect appears to depend on the high hydrophobicity of $\mathrm{CO}$, which would disrupt the lipid bilayer of the cell membrane, increasing proton permeability. To improve the antibiofilm-associated properties of $\mathrm{CO}$ and to balance its toxicity in high concentrations, this compound could be mixed with different excipients, such as EDTA or chitosan [11, 14]. The mechanism of action of EDTA is based on its ability to remove $\mathrm{Mg}^{2+}$ and $\mathrm{Ca}^{2+}$ ions from the external cell wall of Gram-negative bacteria, affecting the integrity of the bacterial membrane [27]. On the other hand, the natural polymer chitosan is widely used as wound dressing [1,4] and as antibacterial agent. Interestingly, the depolymerization process of chitosan by means of gamma radiation increases its antimicrobial effects, according to previous studies $[2,15]$.

For these reasons, the aim of this work was to develop a new treatment based on CO, EDTA, and irradiated chitosan against persistent wound microorganisms.

\section{Materials and Methods}

\section{Materials}

Chitosan (low-molecular-weight), and glacial acetic acid were obtained from Sigma-Aldrich ${ }^{\circledR}$ (Merck KGaA01, 104 Darmstadt, Germany), whereas disodium EDTA, CO, and polysorbate 80 were purchased from Droguería Cosmopolita (Mexico City, Mexico). Argentafil ${ }^{\circledR}$ silver sulfadiazine (Grossman Laboratories, Mexico) was employed as reference for the antimicrobial and antibiofilm tests. The microorganisms utilized were Escherichia coli $\left(\mathrm{ATCC}^{\circledR} 25922^{\mathrm{TM}}\right.$ ), Staphylococcus aureus (ATCC ${ }^{\circledR} 2913^{\mathrm{TM}}$ ), Pseudomonas aeruginosa $\left(\mathrm{ATCC}^{\circledR} 27853^{\mathrm{TM}}\right.$ ) and Candida albicans. Preparation of samples

A solution of chitosan in acetic acid $(2 \% \mathrm{w} / \mathrm{v})$ was irradiated under cobalt-60 gamma irradiation at a dose of $25 \mathrm{KGy}$. The irradiated chitosan was mixed with EDTA, maintaining constant stirring until EDTA was completely dissolved. $\mathrm{CO}$ and polysorbate 80 (Tween 80) were mixed and added drop-wise into the irradiated chitosan-EDTA solution. Stirring was conserved until homogeneity and the $\mathrm{pH}$ was controlled to maintain a value of 5.0. The final formulation was filtered using $0.20 \mu \mathrm{m}$ membranes.

Table I

Concentrations of irradiated formulation with cinnamon oil $\mathrm{pH} 5.0$

\begin{tabular}{|c|c|}
\hline Excipient & Concentration (\%) \\
\hline Cinnamon oil & $0.93 \% \mathrm{v} / \mathrm{v}$ \\
\hline Disodium EDTA & $1.86 \% \mathrm{w} / \mathrm{v}$ \\
\hline Irradiated chitosan & $1.85 \% \mathrm{w} / \mathrm{v}$ \\
\hline Tween 80 & $4.63 \% \mathrm{v} / \mathrm{v}$ \\
\hline Acetic acid $0.5 \%$ & $90.73 \% \mathrm{v} / \mathrm{v}$ \\
\hline
\end{tabular}

Table 1 presents the concentrations employed for elaboration of the formulation. Regarding the physicochemical characterization, the formulation and excipients were lyophilized $\left(-49^{\circ} \mathrm{C}, 0.05 \mathrm{mBar}\right.$, and $\left.24 \mathrm{~h}\right)$.

Physicochemical characterization

Infrared spectroscopy (FT-IR)

To determine the possible interactions of the formulation excipients, lyophilized samples were analysed by FT-IR using an FTIR Nicolet 6700 (Thermo Fisher Scientific $^{\circledR}$, USA). The scanning range was 4000 $400 \mathrm{~cm}^{-1}$.

Thermogravimetric analysis (TGA)

To evaluate the thermal stability of the excipients and the formulation, lyophilized samples were tested using a calorimeter (Q5000; TA Instruments, DE, USA) at a heating rate of $10^{\circ} \mathrm{C} / \mathrm{min}$, with a temperature range of $0-800^{\circ} \mathrm{C}$, and under a nitrogen atmosphere.

Differential scanning calorimetry (DSC)

To evaluate the thermal properties of the excipients and the formulation, the lyophilized samples were tested using a calorimeter (Q2000; TA Instruments, $\mathrm{DE}, \mathrm{USA}$ ) at a heating rate of $10^{\circ} \mathrm{C} / \mathrm{min}$, with a temperature range of $20-350^{\circ} \mathrm{C}$, under a nitrogen atmosphere.

Antimicrobial test

To evaluate the antimicrobial activity of the formulation, the disk diffusion test was employed [3]. Microbial strains of Escherichia coli (ATCC ${ }^{\circledR} 25922^{\mathrm{TM}}$ ), Staphylococcus aureus (ATCC ${ }^{\circledR} 2913^{\mathrm{TM}}$ ), Pseudomonas aeruginosa $\left(\mathrm{ATCC}^{\circledR} 27853^{\mathrm{TM}}\right.$ ) and Candida albicans were inoculated onto Müeller-Hinton agar plates, at a concentration of $1.5 \times 10^{8} \mathrm{CFU} / \mathrm{mL}$. Sterile filterpaper discs ( $5 \mathrm{~mm}$ in diameter) were impregnated with each of the samples and placed in the inoculated agar. Then, the plates were incubated at $37^{\circ} \mathrm{C}$ for $48 \mathrm{~h}$. After the incubation time, the inhibition zones were measured. The experiment was performed three times in independent sessions.

Anti-biofilm test

To analyse the anti-biofilm activity of the formulation, the disk diffusion method in agar was applied. For strains of Escherichia coli and Pseudomonas aeruginosa the Müeller-Hinton agar was employed; whereas for Staphylococcus aureus and Candida albicans, the Müeller-Hinton agar was supplemented with sheep blood 5\%. Argentafil ${ }^{\circledR}$ silver sulfadiazine $1 \%$ was used as positive control, whereas as negative control injectable water was selected. Each agar plate was inoculated with the microorganisms $\left(1.5 \times 10^{8} \mathrm{CFU} /\right.$ $\mathrm{mL}$ ) and incubated at $37^{\circ} \mathrm{C}$ for $24 \mathrm{~h}$ to form the biofilm. Subsequently, the disks impregnated with the solutions-of-interest (formulation, negative and positive controls) were placed on the plates and incubated for $12 \mathrm{~h}$ at $37^{\circ} \mathrm{C}$, after which the zones of inhibition surrounding the antibiotic disks were measured and recorded. The experiment was performed three times in independent trials. 


\section{Results and Discussion}

In this work, a new treatment for the inhibition of opportunistic microorganisms in wound healing based on CO, irradiated chitosan, and EDTA (pH 5.0) was elaborated, characterized, and evaluated in vitro.

\section{Physicochemical characterization}

\section{FT-IR}

In Figure 1, the FT-IR spectra of the excipients and formulation are presented. In the IR spectrum of disodium EDTA (line a), the stretch of the $\mathrm{C}=\mathrm{O}$ bond was able to be identified, which was found to be $1,674 \mathrm{~cm}^{-1}$, whereas the stretch of the $-\mathrm{CH}_{2}$ and $-\mathrm{OH}$ bonds were observed at 1,476 and $1,390 \mathrm{~cm}^{-1}$, respectively. Lines (b) and (c) reveal the FT-IR spectra corresponding to chitosan and irradiated chitosan, respectively. In agreement with the literature [18], on chitosan, a typical band was observed at 3450 $\mathrm{cm}^{-1}$, corresponding to the $-\mathrm{OH}$ group, while at $2883 \mathrm{~cm}^{-1}$, the band related to the $-\mathrm{CH}_{2}$ stretching vibration was found. In addition, the bands of $-\mathrm{NH}_{2}$ and $-\mathrm{CH}_{3}$ vibration were observed at 1595 and at $1374 \mathrm{~cm}^{-1}$, respectively [12]. On the other hand, in the irradiated chitosan spectra, the bands of the main functional groups are also clearly present. However, interestingly, the intensity of the peaks within the range from $1650-800 \mathrm{~cm}^{-1}$ was higher than the peaks of un-irradiated chitosan. This behaviour could be explained by the depolymerization of the chitosan, which generates bonus $\mathrm{C}=\mathrm{O}$ functional groups [31]. Finally, the formulation spectrum demonstrated the characteristic bands of the excipients (Figure 1, line d), proving the cohesion of the excipients.

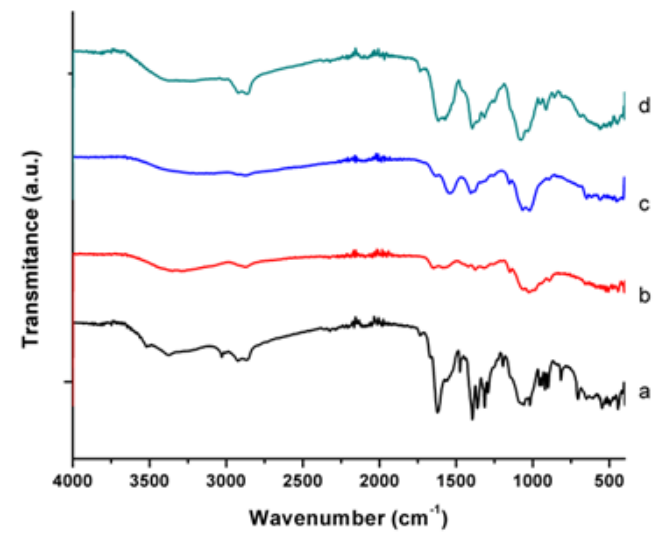

Figure 1.

FT-IR spectra of: EDTA (a), chitosan (b), irradiated chitosan (c) and the formulation (d)

\section{Thermogravimetric analysis}

The thermograms of the excipients and the formulation are presented in Figure 2. Line (a) depicts the thermogram of EDTA. For chitosan (line b), a slight loss of mass related to the humidity of the samples is observed between 40 and $150^{\circ} \mathrm{C}$. Likewise, the second thermal event, observed between 270 and $310^{\circ} \mathrm{C}$ is related to chitosan decomposition, involving the depolymerization phenomena and degradation of the glucopyranose units and their subsequent oxidation. It is noteworthy that, for the irradiated chitosan (line c), degradation reactions were found between $130^{\circ} \mathrm{C}$ and $360^{\circ} \mathrm{C}$, suggesting that the molecular weight is lower than that of the un-irradiated chitosan, due to that it requires a lower temperature to achieve degradation [12]. This behaviour suggests that the thermal stability of the chitosan molecule decreases when it is modified, particularly, by gamma radiation [10]. Finally, the thermogram of the formulation (line d) presents thermal events at 98,140 and $220^{\circ} \mathrm{C}$, approximately. The differences between the thermograms, ( $a, b, c$ and d), could be due to the interactions and cohesion between the excipients into the formulation. This result, along with those of the IR analysis, show that new bonds exist in the formulation.

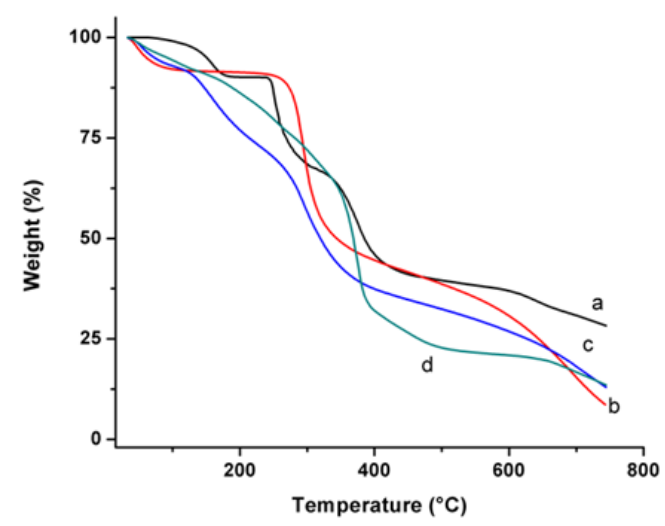

Figure 2.

Thermograms of EDTA (a), chitosan (b), irradiated chitosan (c) and the formulation (d)

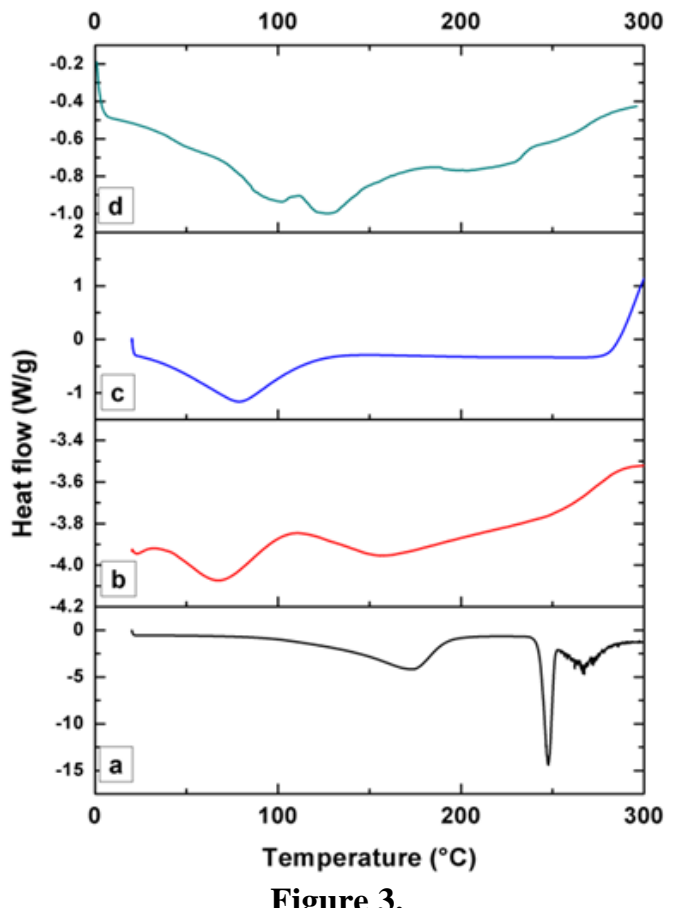

DSC profiles of EDTA (a), chitosan (b), irradiated chitosan (c) and the formulation (d) 
Differential scanning calorimetry

Figure 3 presents the first thermal event for chitosan and irradiated chitosan (lines (b) and (c), respectively) between $20^{\circ} \mathrm{C}$ and $130^{\circ} \mathrm{C}$, which corresponds to an endothermic peak associated with the evaporation of water. Likewise, the thermal event for chitosan (line b) that begins at $300^{\circ} \mathrm{C}$ could indicate degradation of the molecule $[8,9,24,25]$. As can be observed, there are slight changes between the DSC profile of chitosan (line b) and that of the irradiated chitosan (line c). This difference could be related to the depolymerization of the chitosan chain. Finally, line (d) shows the thermal profile of the formulation; similarly to the TGA profile, the thermal events of the excipients are mixed due to the interaction of these in the process of obtaining the formulation.

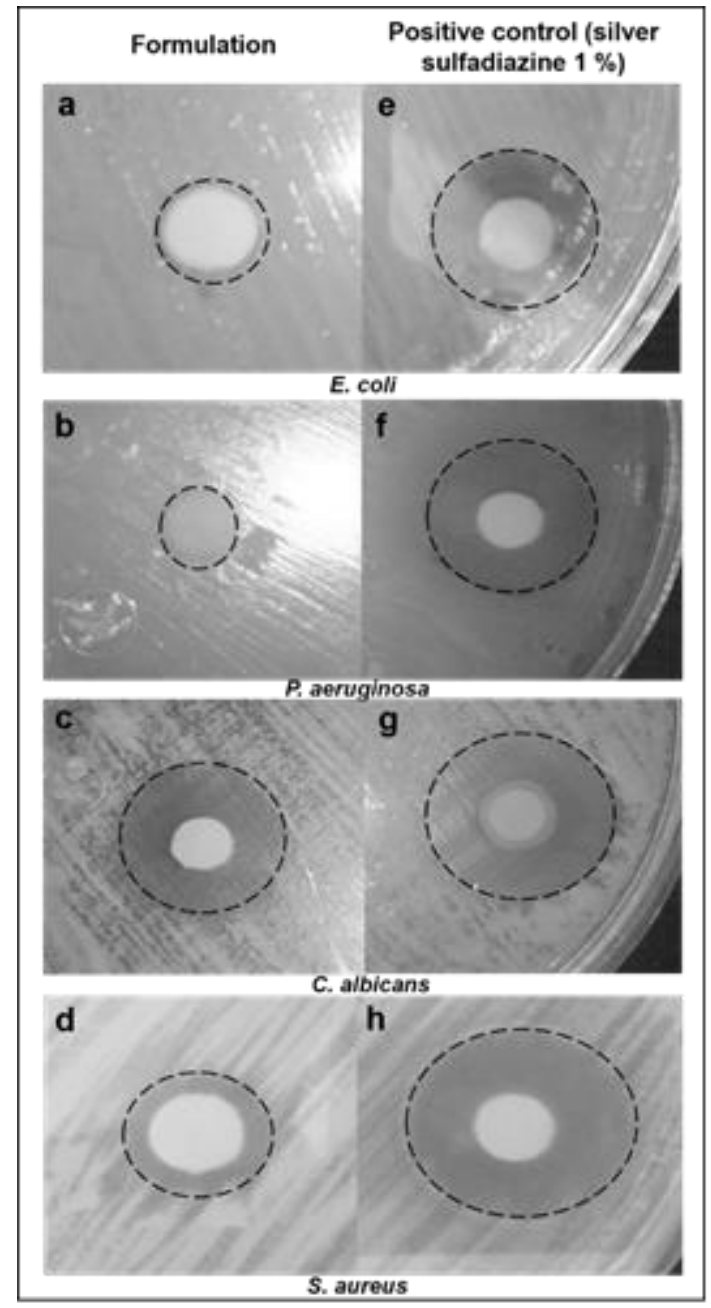

Figure 4.

Inhibition halo of formulation ( $a, b, c$ and $d$ ) and positive control, silver sulfadiazine $1 \%(\mathrm{e}, \mathrm{f}, \mathrm{g}$ and $\mathrm{h})$

\section{Antimicrobial test}

In order to determine the antimicrobial capacity of the new formulation, inhibition tests were performed on four of the characteristic strains considered as opportunistic in wound healing. The zone of inhibition was measured after $48 \mathrm{~h}$ of incubation; these results are shown in Figure 4. The percentage of inhibition of the formulation with respect to the positive control was $43.64 \%$ for $E$. coli (p < 0.05), $42.86 \%$ for $P$. aeruginosa (p < 0.05), $80.27 \%$ for C. albicans (ns), and $42.31 \%$ for $S$. aureus ( $<<0.05$ ). Although the positive control exhibited a higher microbial inhibition compared to the formulation, it should be considered that the formulation is not an antibiotic itself. Silver sulfadiazine is a treatment-of-first-choice in hospitals in several countries worldwide, but also there are reports of slight resistance to silver [19].

In this regard, our formulation combines the antimicrobial mechanisms of disodium EDTA, irradiated chitosan in acid medium, $\mathrm{CO}$, and avoids the use of silver. All of these components show antimicrobial activity; thus, their combination renders the formulation a potent natural option. Interestingly, the formulation revealed the highest percentage of inhibition against the C. albicans strain (Figure 5).

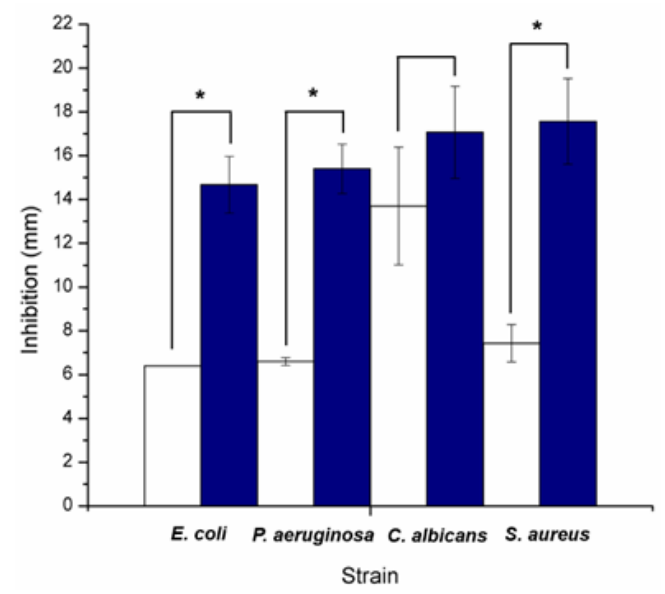

Figure 5.

Bacterial inhibition of formulation (white bars) $v s$ positive control, silver sulfadiazine $1 \%$ (blue bars)

* Indicates $\mathrm{p}<0.05$ as statistically significant

This polymorphic fungus is a member of the normal human microbiome. Although it usually resides as a life-long harmless commensal, under certain circumstances it can cause infections that range from superficial infections of the skin to life-threatening systemic infections [16, 22]. The inhibitory action of the formulation vs. C. albicans could be related to the presence of EDTA, because this agent possesses an antifungal potential. This effect could be explained by the chelating property of EDTA, which plays a critical role in morphogenesis and pathogenesis of C. albicans [22]. Likewise, the inhibition of different strains by $\mathrm{CO}$ has already been investigated, demonstrating interesting results. Prabuseenivasan et al. [20] investigated the microbial inhibition produced by different types of natural oils; for $\mathrm{CO}$, inhibition vs. S. aureus, $P$. aeruginosa, and E. coli was 13.7, 21 and $21 \mathrm{~mm}$, respectively. These values are higher than those of 
the tested formulation (7.3, 6.6 and $6 \mathrm{~mm}$, respectively). However, the concentration of $\mathrm{CO}$ employed by Prabuseenivasan et al. [20] was 1:20, whereas that for our experiment was 1:100, indicating that the level of inhibition is dose-related. In a similar approach, Carvalhinho et al. [7] explored the inhibition of CO $(15 \mu \mathrm{L})$, obtaining a halo of $35 \mathrm{~mm}$. These results indicate that a high concentration of $\mathrm{CO}$ is necessary to obtain a remarkable inhibition; however, it should be noted that high concentrations of this natural essential oil may produce cytotoxic effects [23]. On the other hand, antifungal activity against $C$. albicans is greater when the molecular weight of chitosan is low and the degree of deacetylation is high. Chitosan interacts with the cell wall due to the presence of sialic acid on surface, which causes an alteration in permeability, consequently, the filtration of intracellular components can inhibit the synthesis of DNA and RNA [26]. The inhibitory effect of the formulation on C. albicans is especially important for the treatment of chronic wounds, such as diabetic foot ulcers, where Candida spp. is predominant and resistant to the action of antifungal and antimicrobial agents such as amphotericin B, chlorhexidine, nystatin and fluconazole [17].

Antibiofilm test

Biofilms are complex structures involving different species of microorganisms, embedded in a polysaccharide matrix. Due to their structure, biofilms are resistant to disinfectants or detergents and lead to complications in many fields, such as in the food industry and in medical surgery. The antibiofilm activity of the formulation and the positive control against $P$. aeruginosa can be observed in Figure 6. Interestingly, the formulation presented an average of $13 \mathrm{~mm}$ of inhibition halo, while the positive control, which is widely used for the treatment of chronic wounds, did not exhibit activity vs. biofilm. Diverse mechanisms could explain the antibiofilm activity demonstrated by the formulation. For example, it has been reported that acetic acid could eradicate the mature biofilms of $P$. aeruginosa, even at low concentrations such as $0.5 \%$ [5]. Furthermore, the authors reported that in acetic acid at different values of $\mathrm{pH}(4.33-6)$, the acid was completely bactericide, killing all tested bacteria. On the other hand, chelating agents such as EDTA are capable of destabilizing biofilm sequestering iron, zinc, magnesium and calcium [21], in addition to the mechanisms of destabilization by the electrostatic charges of chitosan. Therefore, the combined antimicrobial effect of the excipients of the formulation obtained represents an alternative against biofilms produced by $P$. aeruginosa, compared with Argentafil ${ }^{\circledR}$ silver sulfadiazine, as treatment for wounds. An antibiofilm effect against the other bacteria was not observed in the evaluated concentration nor with the positive control.

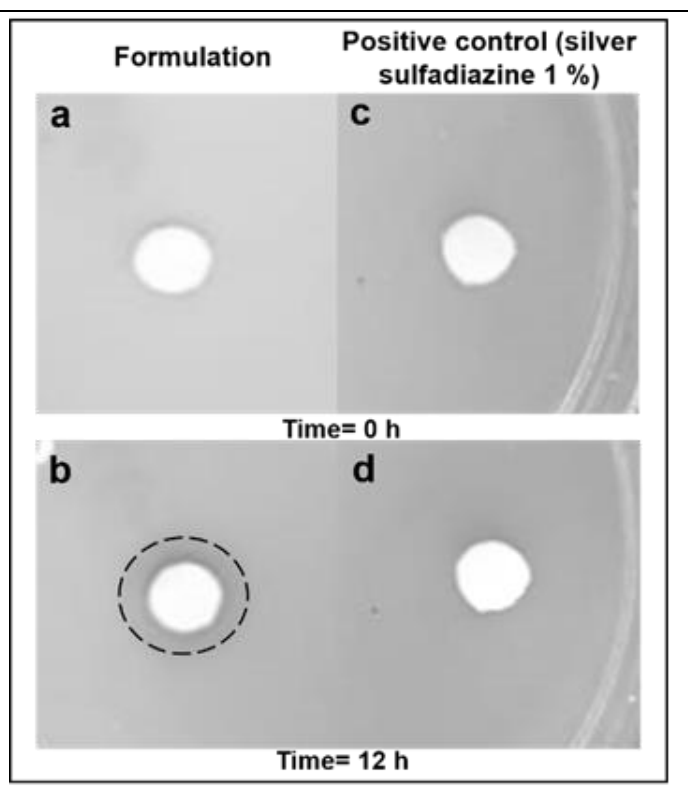

Figure 6.

Inhibition halo in $P$. aeruginosa biofilm of the formulation at $0 \mathrm{~h} \mathrm{(a)}$ and at $12 \mathrm{~h}$ (b); positive control, silver sulfadiazine $1 \%$ at 0 (c) and at $12 \mathrm{~h} \mathrm{(d)}$

\section{Conclusions}

The mechanisms of bacterial resistance to antibiotics remain a serious health problem worldwide, and molecular alternatives are still limited. Particularly, during the healing progresses of severe wounds, the health state of patients becomes critical due to infectious processes. In this work, we developed a new antiseptic solution consisting of $\mathrm{CO}$, chitosan modified by gamma irradiation, and EDTA. In addition, this study addressed a strategy of diluted CO to reduce the toxic effects on damaged tissue and took advantage of combined antimicrobial effects with EDTA and chitosan. The results indicated a percentage of effectiveness of between $50 \%$ and $80 \%$ against opportunistic bacteria and the biofilm of $P$. aeruginosa. Although the formulation is not an antibiotic form, it could be an excellent option for application as treatment in chronic wounds, considering the phenomenon of bacterial resistance. Therefore, this new proposal represents a biocompatible alternative of clinical interest to eradicate biofilms.

\section{Acknowledgement}

This work was supported by a DGAPA-UNAM grant (PAPIIT TA 200318) to Gerardo Leyva-Gómez.

\section{Conflict of interest}

The authors declare no conflict of interest.

\section{References}

1. Agrawal P, Soni S, Mittal G, Bhatnagar A, Role of Polymeric Biomaterials as Wound Healing Agents. Int J Low Extrem Wounds, 2014; 13(3): 180-190. 
FARMACIA, 2021, Vol. 69, 3

2. Bano I, Afzal M, Yasin T, Huang Q, Souza AD, Characterization and potential applications of gamma irradiated chitosan and its blends with poly(vinyl alcohol). Int J Biol Macromol., 2014; 65: 81-88.

3. Bauer AW, Kirby WMM, Sherris JC, Turck M, Antibiotic Susceptibility Testing by a Standardized Single Disk Method. Am J Clin Pathol., 1966; 45: 493-496.

4. Berger J, Reist M, Mayer JM, Felt O, Peppas NA, Gurny R, Structure and interactions in covalently and ionically crosslinked chitosan hydrogels for biomedical applications. Eur J Pharm Biopharm., 2004; 57(1): 19-34.

5. Bjarnsholt $T$, Alhede $M$, Jensen $P \varnothing$, Nielsen $A K$, Johansen HK, Homøe P, Høiby N, Givskov M, Kirketerp-Møller K, Antibiofilm Properties of Acetic Acid. Adv Wound Care., 2015; 4(7): 363-372.

6. Bowler PG, Parsons D, Combatting wound biofilm and recalcitrance with a novel anti-biofilm Hydrofiber $^{\circledR}$ wound dressing. Wound Med., 2016; 14: 6-11.

7. Carvalhinho S, Costa AM, Coelho AC, Martins E, Sampaio A, Susceptibilities of Candida albicans Mouth Isolates to Antifungal Agents, Essentials Oils and Mouth Rinses. Mycopathologia, 2012; 174(1): 69-76.

8. Chandra Dey S, Al-Amin M, Ur Rashid T, Sultan Z, Ashaduzzaman Md, Sarker M, Shamsuddin S, Performance evaluation of Chitosan as an adsorbent for remazol red. Int $J$ Latest Res Eng Technol., 2016; 2(2): 52-62.

9. Corazzari I, Nisticò R, Turci F, Faga MG, Franzoso F, Tabasso S, Magnacca G, Advanced physico-chemical characterization of chitosan by means of TGA coupled on-line with FTIR and GCMS: Thermal degradation and water adsorption capacity. Polym Degrad Stab., 2015; 112: 1-9.

10. El-Nesr EM, Raafat AI, Nasef SM, Soliman EA, Hegazy E-SA, Radiation Synthesis and Characterization of N,O-Carboxymethyl Chitosan/poly(vinylpyrrolidone) Copolymer Hydrogel. Arab J Nucl Sci Appl., 2014; 47(1): 14-27.

11. Finnegan S, Percival SL, EDTA: An Antimicrobial and Antibiofilm Agent for Use in Wound Care. $A d v$ Wound Care., 2015; 4(7): 415-421.

12. García MA, De la Paz N, Castro C, Rodríguez JL, Rapado M, Zuluaga R, Gañán P, Carariego A, Effect of molecular weight reduction by gamma irradiation on the antioxidant capacity of chitosan from lobster shells. J Radiat Res Appl Sci., 2015; 8(2): 190-200.

13. Lee CJ, Chen LW, Chen LG, Chang TL, Huang $\mathrm{CW}$, Huang $\mathrm{MC}$, Wang $\mathrm{CC}$, Correlations of the components of tea tree oil with its antibacterial effects and skin irritation. J Food Drug Anal., 2013; 21(2): 169-176.

14. Liu Z, Lin Y, Lu Q, Yu J, Wang Z, He Y, Song C, In vitro and in vivo activity of EDTA and antibacterial agents against the biofilm of mucoid Pseudomonas aeruginosa. Infection, 2017; 45(1): 23-31.

15. Matsuhashi S, Kume T, Enhancement of Antimicrobial Activity of Chitosan by Irradiation. J Sci Food Agric., 1997; 73: 237-241
16. Mayer FL, Wilson D, Hube B, Candida albicans pathogenicity mechanisms. Virulence, 2013; 4(2): 119-128.

17. Mukherjee PK, Chandra J, Kuhn DM, Ghannoum MA, Mechanism of fluconazole resistance in Candida albicans biofilms: Phase-specific role of efflux pumps and membrane sterols. Infect Immun., 2003; 71(8): 4333-4340.

18. Negrea P, Caunii A, Sarac I, Butnariu M, The study of infrared spectrum of chitin and chitosan extract as potential sources of biomass. Dig J Nanomater Biostructures., 2015; 10(4): 1129-1138.

19. Percival SL, Salisbury AM, Chen R, Silver, biofilms and wounds: resistance revisited. Crit Rev Microbiol., 2019; 45(2): 223-237.

20. Prabuseenivasan S, Jayakumar M, Ignacimuthu S, In vitro antibacterial activity of some plant essential oils. BMC Complement Altern Med., 2006; 6: 1-8.

21. Roy R, Tiwari M, Donelli G, Tiwari V, Strategies for combating bacterial biofilms: A focus on anti-biofilm agents and their mechanisms of action. Virulence, 2018; 9(1): 522-554.

22. Sen BH, Akdeniz BG, Denizci AA, The effect of ethylenediamine-tetraacetic acid on Candida albicans. Oral Surg Oral Med Oral Pathol Oral Radiol Endod., 2000; 90(5): 651-655.

23. Serra E, Hidalgo-Bastida LA, Verran J, Williams D, Malic S, Antifungal activity of commercial essential oils and biocides against Candida albicans. Pathogens, 2018; 7(1): 1-12.

24. Singh K, Suri R, Tiwary AK, Rana V, Chitosan films: crosslinking with EDTA modifies physicochemical and mechanical properties. J Mater Sci Mater Med., 2012; 23(3): 687-695

25. Singh K, Tiwary AK, Rana V, Ethylenediaminediacetic acid bis(carbido amide chitosan): Synthesis and evaluation as solid carrier to fabricate nanoemulsion. Carbohydr Polym., 2013; 95(1): 303-314.

26. Tayel AA, Moussa S, El-Tras WF, Knittel D, Opwis $\mathrm{K}$, Schollmeyer E, Anticandidal action of fungal chitosan against Candida albicans. Int J Biol Macromol., 2010; 47(4): 454-457.

27. Umerska A, Strandh M, Cassisa V, Matougui N, Eveillard M, Saulnier P, Synergistic Effect of Combinations Containing EDTA and the Antimicrobial Peptide AA230, an Arenicin-3 Derivative, on GramNegative Bacteria. Biomolecules, 2018; 8(4): 122: $1-13$.

28. Velnar T, Bailey T, Smrkolj V, The Wound Healing Process: An Overview of the Cellular and Molecular Mechanisms. J Int Med Res., 2009; 37: 1528-1542.

29. Wińska K, Mączka W, Łyczko J, Grabarczyk M, Czubaszek A, Szumny A, Essential Oils as Antimicrobial Agents - Myth or Real Alternative?. Molecules, 2019; 24(11): 2130: 1-21.

30. Wu H, Moser C, Wang HZ, Høiby N, Song ZJ, Strategies for combating bacterial biofilm infections. Int J Oral Sci., 2015; 7: 1-7.

31. Zainol I, Akil HM, Mastor A, Effect of $\gamma$-irradiation on the physical and mechanical properties of chitosan powder. Mater Sci Eng C., 2009; 29(1): 292-297 